\title{
STUDY ON UNDERAGE MARRIAGE IN EMPAT LAWANG REGENCY VIEWED FROM THE LAW OF THE REPUBLIC OF INDONESIA NUMBER 16 OF 2019 IN CONJUNCTION WITH LAW NUMBER 1 OF 1974 ABOUT MARRIAGE
}

\author{
By : \\ Alfha Sulindra, M. Darudin, Sirman Dahwal
}

\begin{abstract}
Underage marriage is a marriage bond between a man and a woman, where the age of both or one of them has not reached the limits stipulated in Law of the Republic of Indonesia Number 16 of 2019 in conjunction with Law of the Republic of Indonesia Number 1 of 1974 about Marriage. Underage marriage is one of the legal acts that is not justified by the law of marriage. However, in reality in Empat Lawang Regency it is still practiced, and even the number of underage marriages is still high. The formulation of the problems in this study were: (1) How was the underage marriage in Empat Lawang Regency viewed from the Law of the Republic of Indonesia Number 16 of 2019 in conjunction with Law of the Republic of Indonesia Number 1 of 1974 about Marriage? (2) What were the factors causing the high rate of underage marriage in Empat Lawang Regency? (3) How was the impact of underage marriage on the harmony of domestic life? The research method applied in this study was juridical empirical. The results of this study indicated that: (1) Underage marriage in Empat Lawang Regency had been carried out according to Law of the Republic of Indonesia Number 16 of 2019 in conjunction with Law of the Republic of Indonesia Number 1 of 1974 concerning Marriage, if the prospective husband and wife had not met the requirements as regulated in the Law, then the prospective husband and wife must apply for dispensation to the Religious Court for approval of marriage permits. (2) The factors causing the high rate of underage marriages in Empat Lawang Regency consisted of being pregnant outside of marriage (married by accident), worrying that their child will fall into promiscuity, pressure from parents, lack of economic stability, desire of lasting relationship, family traditions, lack of parental supervision of children, lack of sex education, and parental mindset. (3) The impact of underage marriage on the harmony of household life was the difficulty to form such a harmonious household.
\end{abstract}

Keywords : Underage Marriage, Law of the Republic of Indonesia Number 16 of 2019, Causative Factors. 


\section{A. INTRODUCTION}

\section{Research Background}

Underage marriage is a physical and mental bond between a man and a woman as husband and wife at a young age or under age.

Underage marriage is a marriage that occurs at the age of less than 19 years, and which occurs in adolescence. Marriage under the age of 19 is against the child's right to education, pleasure, health, freedom of expression. To build a quality family requires physical and mental maturity. It is advisable for men to marry after the age of 25 because at that age men are considered mature physically and spiritually. Women are encouraged to marry after the age of 20 because at that age the woman has completed growth and the uterus is performing its functions optimally. ${ }^{1}$

${ }^{1}$ Syarifudin, "Perkawinan Dibawah Umur", downloaded on December 25, 2019 from https://www.bing.com/search?q=tininjau+ pustaka+marriage+ at+ bottom+ ages
This underage marriage occurs in several regions in Indonesia. There is a lot of information about underage marriages that can be found both in print and electronic media. One of the information regarding underage marriage that has attracted a lot of attention was:

Based on data from the National Central Bureau of Statistics, there are indications of underage marriage in almost all regions of Indonesia. However, there are several provinces recorded as having high child marriage rates. Some of these provinces are South

Sumatera Province (30.23 percent), West Sulawesi Province (34 percent), South Kalimantan Province (33.68 percent), Central Kalimantan Province (33.56 percent), West Kalimantan Province (32.21 percent), and 
Central Sulawesi Province (31.91 percent). ${ }^{2}$

Based on the information above, it can be seen that underage marriages are still widely practiced in Indonesia, not only in West Sulawesi Province, Central Sulawesi Province, West Kalimantan Province, Central Kalimantan Province, South Kalimantan Province, but also in South Sumatera Province.

Seeing the high number of underage marriages in Empat Lawang Regency, actually underage marriage itself is an act that is not allowed, and even if it is allowed, it must be subject to certain conditions, as stipulated in Article 7 of Law of the Republic of Indonesia Number 16 of 2019 about Amendments to Law of the Republic of Indonesia

2 Endro Prihardityo, "Perkawinan Usia Anak Masih Marak Di Indonesia", downloaded on December 25, 2019 from https://www.cnnindonesia.com/gayahidup/20160723074431-277-146515/perk Marriage-usia-anak-masih-marak-diIndonesia
Number 1 of 1974 concerning Marriage.

However, in reality, Empat Lawang Regency is still practicing underage marriage, even the number of underage marriages is still high. Seeing this, the writer feel the need to conduct a research and study of underage marriage in Empat Lawang Regency in terms of the Law of the Republic of Indonesia Number 16 of 2019, and the factors causing the high rate of underage marriage in Empat Lawang Regency.

Based on background above, the researcher interested in raising the problem as a scientific work in the form of a thesis entitled "Study on Underage Marriage in Empat Lawang Regency Viewed from the Law of the Republic of Indonesia Number 16 of 2019 in conjunction with Law of the Republic of Indonesia Number 1 of 1974 about Marriage".

\section{Identification of the Problems}


Based on the background description above, the problems in this study were:

1) How was the underage marriage in Empat Lawang Regency viewed from the Law of the Republic of Indonesia Number 16 of 2019 in conjunction with Law of the Republic of Indonesia Number 1 of 1974 about Marriage?

2) What were the factors causing the high rate of underage marriage in Empat Lawang Regency?

3) How was the Impact of underage marriage on the harmony of domestic life ?

\section{B. RESEARCH METHODS}

This study was an empirical juridical research with descriptive research type. The data sources used were primary and secondary data. Data processing was performed by using the editing method. Then data analysis was carried out by using qualitative analysis method.

\section{RESULTS AND DISCUSSION}

1. Underage Marriage in Empat

Lawang Regency Viewed from

the Law of the Republic of Indonesia Number 16 of 2019 in conjunction with Law of the Republic of Indonesia Number 1 of 1974 about Marriage

a. Judge at the Lahat District Religious Court

Based on the results of the interviews obtained from 3 (three) Judges, if it was related to the implementation theory which states that successful implementation includes the extent to which the interests of the target group are contained in the contents of the regulations and whether a program is supported by adequate resources, then underage marriages in Empat Lawang Regency had implemented the provisions of Law of the Republic of Indonesia Number 16 of 2019 in conjunction with Law of the Republic of Indonesia Number 1 of 1974 about Marriage, which includes the target group in the form of underage 
marriage partners, and those who determines whether or not the underage marriage can be performed, were the competent judges.

Furthermore, if it was related to the theory of legal effectiveness which states that if legal norms are obeyed and implemented by the community and legal officials, then the law enforcement is said to be effective or successful. Based on the results of interviews with 3 (three) judges, the Law of the Republic of Indonesia Number 16 of 2019 in conjunction with Law of the Republic of Indonesia Number 1 of 1974 concerning Marriage, had been obeyed by the community and had been implemented by judges in Empat Lawang Regency.

\section{b. Head of the District Office of Religious Affairs in Empat Lawang Regency}

Based on the results of interviews obtained from 5 (five) Heads of the District
Office of Religious Affairs (known as KUA in Indonesian abbreviation), if it was related to the implementation theory which states that successful implementation includes the extent to which the interests of the target group are contained in the contents of the regulations and whether a program is supported by adequate resources, then the underage marriages in Empat Lawang Regency had implemented the provisions of Law of the Republic of Indonesia Number 16 of 2019 in conjunction with Law of the Republic of Indonesia Number 1 of 1974 concerning Marriage, which includes the target group in the form of underage marriage partners, and for the District Office of Religious Affairs it has been implemented by the professional Head of the Heads of the District Office of Religious Affairs (KUA).

Furthermore, if it was related to the theory of legal 
effectiveness which states that if legal norms are obeyed and implemented by the community and legal officials, then the law enforcement is said to be effective or successful. Based on the results of interviews with 5 (five) Heads of the District Office of Religious Affairs (KUA), Law of the Republic of Indonesia Number 16 of 2019 in conjunction with Law of the Republic of Indonesia Number 1 of 1974 concerning Marriage has been obeyed and implemented by the community and the District Office of Religious Affairs (KUA) by not marrying underage partners, namely, marriage partners where the male and female parties have not reached the age of 19 years, unless they have received a marriage dispensation from the Lahat Religious Court.

Based on the research data and data analysis above, it can be seen that, underage marriage in Empat Lawang Regency has been carried out in accordance with the provisions of Law of the Republic of Indonesia Number 16 of 2019 in conjunction with Law of the Republic of Indonesia Number 1 of 1974 concerning Marriage, both regarding the minimum age requirement, conditions and methods for applying for dispensation if there is a deviation from the minimum age requirement, and the legal basis for refusing or granting dispensation of underage marriage.

\section{Factors Causing the High Rate} of Underage Marriage in Empat Lawang Regency

\section{a. Judge at the Lahat District Religious Court}

Based on the results of interviews with 3 (three) Judges at the Lahat Religious Court, it was obtained information that the factors causing the high rate of underage marriage in Empat Lawang were as follows: 
1. The factor of pregnancy out of wedlock (married by accident), this is because children have relationships that violate norms, forcing them to marry underage, in order to clarify the status of the child being conceived.

2. Worrying that their children will fall into promiscuity. Most parents want their children to marry early because they see that the relationship between the two is so close, so they are worried that if they are not married immediately, actions that are prohibited by Islamic law will occur.

3. Pressure from parents. Parents wish for their children to get married early, because they are worried that their children will fall into promiscuity and have negative consequences, because they want to perpetuate the relationship with their relationship by pairing their children with their relatives or their children, matching their children with their relative's children so that the property they have does not fall to other people, but is still held by the family.

4. Family economic factors. Families experiencing economic difficulties will tend to marry off their children at a young age. This marriage is expected to be a solution to the economic difficulties of the family, by getting married it is hoped that it will reduce the economic burden on the family, so that it can overcome economic difficulties.

5. The factor of wanting to perpetuate the relationship, in this case underage marriage is deliberately done and everything has been prepared, because it is done in order to perpetuate the relationship that exists between the two. This causes them to get married at a young age (underage 
marriage), so that their relationship status is certain.

6. The family tradition factor, it can be seen that there are those who have a tradition or the habit of marrying off their children at a young age, and this continues, so that the children in the family will automatically follow this tradition.

\section{b. Head of the District Office of Religious Affairs in Empat Lawang Regency}

Based on The results of interviews with 5 (five) Heads of the District Office of Religious Affairs (KUA), it was obtained information that the factors causing the high rate of underage marriage in Empat Lawang were:

1. Inadequate economic factor makes parents tend to marry off their children at a minor age with a man who is considered economically capable. It is hoped that marrying off these underage children is a solution to the economic difficulties experienced by the family, and is expected to reduce the economic burden on the family.

2. Pregnancy outside of marriage factor, both partners or one of them are still under age, have a relationship like husband and wife and already pregnant with a child, so that both parents are forced to marry them.

3. Lack of parental supervision of children factor, this is because parents are busy working, parents become migrant workers, parents are divorced, and some of the parents are sick so they cannot supervise their children interactions every day, plus they are in a less socially well environment so that the worst impact is pregnancy outside of marriage which requires them to marry underage.

4. Lack of sex education factor, sex education is still 
considered taboo when given, so that the impact is that many children who are not old enough to find out or even try sex without control. The worst consequence is that the child gets pregnant outside of marriage, so whether she wants it or not, even though she is still a minor, she must be married off.

5. Parents' mindset factor, there are still many parents who have a mindset that if the child is already mature and old enough, it is better to get married immediately, even though his age is not sufficient to carry out the marriage.

\section{c. Underage Marriage Couples in Empat Lawang Regency}

Based on the results of interviews with 5 (five) underage marriage partners, it was found that the factor causing the high rate of underage marriage in Empat Lawang Regency was the factor of pregnancy outside of marriage, so that they inevitably married.

Based on the results of interviews with 3 Judges of the Lahat Religious Court, 5 Heads of the District Office of Religious Affairs (KUA) in Empat Lawang Regency, and 5 underage marriage partners in Empat Lawang Regency, it was found that the factors causing the high rate of underage marriage in Empat Lawang Regency were:

1. The factor of pregnancy out of wedlock (married by accident), this is because children have relationships that violate norms, forcing them to marry underage, in order to clarify the status of the child being conceived.

2. Worrying that their children will fall into promiscuity. Most parents want their children to marry early because they see that the relationship between the two is so close, so they are worried that if they are not married immediately, actions that are 
prohibited by Islamic law will occur.

3. Pressure from parents. Parents wish for their children to get married early, because they are worried that their children will fall into promiscuity and have negative consequences, because they want to perpetuate the relationship with their relationship by pairing their children with their relatives or their children, matching their children with their relative's children so that the property they have does not fall to other people, but is still held by the family.

4. Family economic factors. Families experiencing economic difficulties will tend to marry off their children at a young age. This marriage is expected to be a solution to the economic difficulties of the family, by getting married it is hoped that it will reduce the economic burden on the family, so that it can overcome economic difficulties.
5. The factor of wanting to perpetuate the relationship, in this case underage marriage is deliberately done and everything has been prepared, because it is done in order to perpetuate the relationship that exists between the two. This causes them to get married at a young age (underage marriage), so that their relationship status is certain.

6. The family tradition factor, it can be seen that there are those who have a tradition or the habit of marrying off their children at a young age, and this continues, so that the children in the family will automatically follow this tradition.

7. Lack of parental supervision of children factor, this is because parents are busy working, parents become migrant workers, parents are divorced, and some of the parents are sick so they cannot supervise their children interactions every day, plus they are in a less socially well 
environment so that the worst impact is pregnancy outside of marriage which requires them to marry underage.

8. Lack of sex education factor, sex education is still considered taboo when given, so that the impact is that many children who are not old enough to find out or even try sex without control. The worst consequence is that the child gets pregnant outside of marriage, so whether she wants it or not, even though she is still a minor, she must be married off.

9. Parents' mindset factor, there are still many parents who have a mindset that if the child is already mature and old enough, it is better to get married immediately, even though his age is not sufficient to carry out the marriage.

\section{The Impact of Underage} Marriage on the Harmony in Household Life

\section{a. Judge at the Lahat District Religious Court}

Based on the results of interviews with 3 (three) Judges at the Lahat Religious
Court, it was found that the impact of underage marriage to the harmony of domestic life was that it would be difficult to form a harmonious family.

\section{b. Head of the District Office of Religious Affairs in Empat Lawang Regency}

Based on the results of interviews with 5 (five) Heads of the District Office of Religious Affairs (KUA), it was found that the impact of underage marriage on the harmony of household life was that it would be difficult to form a harmonious family.

\section{c. Couple Underage Marriage in Empat Lawang}

Based on the results of interviews with 5 (five) underage marriage partners, it was found that the impact of underage marriage on the harmony of household life was that it would be difficult to form a harmonious family.

Based on the results of interviews with 3 Judges of the Lahat Religious Court, 5 Heads 
of the District Office of Religious Affairs (KUA) in Empat Lawang Regency, and 5 underage marriage partners in Empat Lawang regency, it was found that the impact of underage marriage on the harmony of household life was that it would be difficult to form a harmonious family.

\section{CLOSING}

\section{Conclusions}

1) Underage marriage in Empat Lawang Regency had been carried out according to Law of the Republic of Indonesia Number 16 of 2019 in conjunction with Law of the Republic of Indonesia Number 1 of 1974 about Marriage. If the prospective husband and wife have not met the requirements as regulated in this Law, then prospective married couples must apply for dispensation to the Religious Court to obtain approval for marriage permits.
2) Factors causing the high rate of underage marriage in Empat Lawang Regency were pregnancy outside of marriage, lack of family economic, engagement, committed acts like husband and wife (immoral), lack of parental supervision to the children, lack of sex education, parents' mindset, fear of the children falling into promiscuity, pressure from parents, desire to make a relationship lasting, family traditions, and following local customs.

3) The impact of underage marriage on the harmony of household life was that it would be difficult to form a harmonious family.

\section{Suggestion}

The competent government needs to regularly provide counseling along with religious and community leaders about the negative and positive impacts of underage marriage, and about the provisions of Law of the 
Republic of Indonesia Number

16 of 2019 in conjunction with

Law of the Republic of

Indonesia Number 1 of 1974

concerning Marriage, especially

Article 7 paragraph (1), namely

the age of marriage must be

well understood to avoid

discrimination in the marriage

within the family environment.

\section{REFERENCES}

Syarifudin, "Perkawinan Dibawah Umur", downloaded on December 25, 2019 from https://www.bing.com/search?q=tininjau+pusta ka+marriage+ at + bottom+ ages

Endro Prihardityo, "Perkawinan Usia Anak Masih Marak Di Indonesia", downloaded on December 25, 2019 from https://www.cnnindonesia.com/gayahidup/20160723074431-277-146515/perk Marriage-usia-anak-masih-marak-di-Indonesia 